\title{
IT/IS FACULTY PERCEPTIONS OF THE UNIONIZATION PROCESS OF ADJUNCT FACULTY: A CASE STUDY
}

\author{
Michael J. Curran, Strayer University, michael.curran@strayer.edu \\ Robert Kowalewski, Robert Morris University, rwkst5@mail.rmu.edu \\ Robert J. Trosky, Jr., Robert Morris University, trosky@rmu.edu \\ Carrie A. Payne, Penn State Erie, The Behrend College, cap15@psu.edu
}

\begin{abstract}
The number of course hours adjunct faculty members teach continues to rise in higher education, while treatment of this growing faculty segment remains an area of intense emotion and scrutiny. Universities cite cost savings and adjuncts' specialized educational qualifications as a positive for the university and students. Adjunct faculty members cite cases in which lack of job security and benefits, low pay, and poor treatment and conditions contribute to emotional stress-making the position of adjunct faculty member untenable. In response to this discord, a growing unionization movement has begun among adjunct faculties. Unions, once the primary vehicle for blue collar labor, have embraced this new demographic, and in several cases have helped adjunct faculty members to form unions under the guidelines of the National Labor Relations Board. In this qualitative study, several themes emerged from adjunct faculty members as they went through a process of unionization including issues of isolation and confusion, mixed messages, and fear of uncertainty. The unionization process was perceived as mostly positive for the majority of the participants despite some concerns as the process developed.
\end{abstract}

Keywords: Adjunct Faculty, Union, Qualitative Study, Labor Relations

\section{INTRODUCTION}

In 2014, more than half of the U.S. faculty members and both public and private non-profit colleges were part-time instructors [25, 37]. Universities cite cost savings and adjuncts' educational qualifications as a positive for the university and students [24]. Adjunct faculty members cite cases in which lack of job security and benefits, low pay, and poor treatment and conditions contribute to emotional stress-making the position of adjunct faculty member untenable. In response to this discord, a growing unionization movement has begun among adjunct faculties, despite the recent stagnation and, at some points, steady decline of U.S. membership in labor unions [15, 35]. Unions, once the primary vehicle for blue collar labor, have embraced this new demographic, and in several cases have helped adjunct faculty members to form unions under the guidelines of the National Labor Relations Board [40].

There are many factors that influence the degree to which college faculty, both full-time and adjunct, respond to overtures of unionization $[2,16,27]$. Traditionally, union organization among college faculty has been primarily limited to full-time faculty [27, 34, 40]. However, a new trend in adjunct faculty members seeking union recognition has become an important issue in higher education [3, 23, 28, 42]. Studies also suggest the success factors in these ventures is dependent on a number of often inter-related and challenging factors, including leadership, communication strategy, and commitment [9, 12, 9, 22].

In this study, a mid-sized private university had seen a large labor union attempt to gather support to unionize the adjunct faculty. Adjunct faculty at this university taught over $60 \%$ of the credit hours offered and received no benefits and had no system in place to determine courses, which was generally done ad hoc by department heads, which led to complaints by some faculty that if they 'fell out of favor' with their department head they did not receive classes or were given very unfavorable schedules. At least one faculty adjunct faculty member contacted a large labor union and asked about the process of unionization. This started a process that lasted almost a year, during which the union and the university provided information about this process. During the process both the union organizers and the university administration began to actively communicate with adjuncts advocating their perspectives on what an adjunct faculty union would mean to them personally and to the university as a whole. This process, while sometime very adversarial, provided some of the strongest perspectives among the participants. 
The purpose of this study was to look at how adjunct faculty in the Information Systems/Information Technology Department at this university perceived the process and the impact that this process had on them. As unionization continues to persist as a significant issue in higher education, understanding how this process impacts the faculty group most affected by the process can help both faculty and administrators more effectively work together to provide a stable and positive work environment for all faculty, which would benefit the learning environment for students.

\section{LITERATURE REVIEW}

U.S. membership in labor unions has either stagnated or steadily declined in recent history $[6,11,15,21,40]$. However, adjunct faculties at universities across the U.S. have responded to a lack of acknowledgement of their perceived value by attempting to unionize to address issues of job security, pay, and other concerns $[5,25,29,35]$. In 2014, more than half of the U.S. faculty members and both public and private non-profit colleges were part-time instructors [37]. Liftig [25] examined the numbers: "According to Weissmann, at public 4-year colleges, 36\% of faculty are part-timers; at private 4 -year schools, $51 \%$ are considered "adjunct"; and at American community colleges, over $70 \%$ of the faculties are neither on tenure or teaching in tenure track positions [25, 40]. The average pay per course is $\$ 3,200$ at a public research university and $\$ 2,250$ at a community college [25]."

The issue of unionization of adjunct faculties has become an increasingly important concern in higher education. More than 350 articles and blog posts have been published on the topic in The Chronicle of Higher Education since 2010. The issues that McGee (2002) and Dedman and Pearch [7]) described appear to remain; the employment of adjunct faculty members continues to be cost-effective for the university, and pay and job security continue to be major issues for the adjunct faculty members [7,30]. Schmidt [37], and Liftig [25] among many others report that universities have increased the percentage of classes taught by adjunct faculty members, in part, because they are available to teach specialized courses at a lower cost than full-time, permanent faculty members $[25,37,40]$.

Perceived barriers often exist in the adjunct faculty unionization process including, but not limited to isolation and confusion, mixed messages, and fear of uncertainty. Liftig [25] described his experience with unionization and job security (fear of uncertainty). "The ranks of fellow adjuncts were profoundly afraid: 'We can be fired at any time. You know that," one prospective union member exclaimed to him. The faculty member was correct, Liftig explained, "The next semester, my name disappeared from the course catalog [25]." Schmidt [37] explained that these adjuncts "have long complained about poor pay and working conditions....[and] their options have been to form advocacy groups to publicize their problems, to join education unions dominated by tenure-track faculty members with their own agendas, or to simply quit teaching at colleges." Schmidt further explained the isolation the faculty members experienced. "Adjunct faculty members also tend to spend little time on campus except when they are actually teaching, which can make them difficult to find and otherwise hinder their interaction with fellow faculty members. Their lack of job security can leave them fearful of being associated with a unionization campaign. Those who regard teaching as something they do on the side, on top of some other well-paying job, can be unsympathetic to pleas that they should join a union to improve their peers' working conditions [37]."

Several high profile cases of unionization have highlighted this issue and have made unionization a significant issue for administrators at universities across the nation [34, 40, 41]. Schmidt [37] described the collective efforts of adjunct faculties in U.S. cities, including Boston and Pittsburgh, to enable a competitive environment for universities to obtain adjunct faculty members, rather than a "buyer's market." The organizers suggest that an even playing field among the universities would make university administration more open to unionization and collective bargaining and improve working conditions for adjunct faculty members [37]. The unionization process is complicated by a myriad of issues, including the varied needs of each university [7, 10, 14, 18, 32].

Mixed messages seemed to be an issue at Bentley University, where approximately 40 percent of the faculty member teach about 25 percent of the classes. One adjunct faculty member said that "organizers there 'fostered an aura of optimism' but 'misunderstood the culture," while "faculty advocates of unionization invoked Bentley's emphasis on business ethics to argue that it betrayed its own principles by exploiting part-time instructors," and administration asserted that several current adjunct faculty members said they "would no longer teach here" if they became unionized [37]. 


\section{RESEARCH METHODOLOGY}

\section{Rationale for Using the Case Study Method}

A case study methodology was adopted for this project. A case study is an effective qualitative technique when the researcher has clearly identifiable cases within established boundaries and seeks to provide greater in-depth understanding of a phenomenon, and allows for the emergence of sometimes subtle themes that are consistent throughout the experience $[8,31,36]$. In this case, the boundaries are clear and narrowly defined: the experiences of seven IT/IS adjunct faculty members at a mid-sized private university as they transitioned from their current nonunion environment to one with union representation recognized by the university. Therefore, this situation was appropriate for a case study methodology.

\section{The Participants}

The seven adjunct faculty members that participated in this study were selected based on a convenience sample. The researcher, who also works as an adjunct faculty member at the subject university, had posted a message in the adjunct faculty office asking for participants in a research study on unionization. This took place after the unionization process had concluded and the message asked for people willing to be interviewed to describe their perceptions of the entire process of unionization. Initially a large number of adjunct faculty outside the IS/IT field replied and they were contacted for a further study. Nine people in IS/IT responded to the message and were contacted by the researcher. After initial meetings, two declined to participate further, both citing issues of a lack of time to participate, and the remaining seven served as the population for this study. Each participant attended a brief introductory meeting in which the scope of the research project was explained and participants were asked to complete an informed consent document outlining expectations and privacy issues for this study.

John (all names used are pseudonyms) has taught at the subject university for six years and generally teaches freshman level and introductory IT courses. He also teaches at the adjunct level for two other universities and does not have a full-time position, but has been actively searching for a position for several years. He has applied seven times for full-time faculty positions at the subject university and numerous times at other local schools without success. He holds an MS degree and is not currently working on a terminal degree. He described his overall relationship with the university as "sometimes good, sometimes bad, depending on whom your department head is." He also stated that he is generally well liked by the students and tries to be a part of the overall campus community, "although it's hard because I teach at so many other schools." He also stated that he had grown up in a household that was union friendly, "My dad was in the steel workers union and he really thought unions were great for workers." He also stated that he had never belonged to a union before and generally felt his feelings about labor unions were "generally positive" going into this experience.

Richard has taught at the subject university for nine years and teaches in both the IS and Communications departments. He holds a full-time salaried position in the IT field for a private company and generally teaches one IT/IS or Communications class each semester. He does not teach at any other universities. He holds a terminal degree in Computer Science. He stated that he is not looking for full-time status as a faculty member and described his relationship with the subject university as "pretty good, most of the time" and his relationship with the students as "solid." He stated that his general impressions on labor unions prior to unionization at the subject university as "I don't like them; I think they subsidize poorer quality workers and even though seniority would benefit me, I still think it's a bad idea for the school." He also stated that he had never been in a labor union before although they do have a labor union at his current full-time position and "I've worked with a lot of union members in the past."

Allison has been teaching at the subject university for two years and previously taught full-time at another university in a different state before relocating. She currently teaches two sections of a specialized upper-level course in database management. She holds a terminal degree in IS. She is not teaching at any other universities and is not employed full-time anywhere else. She has applied for several full-time positions at the subject university but has yet to receive any offers to interview and she is also actively looking at other universities for full-time employment. She described her relationship with the university as "a bit strained a lot of the time since I rarely get the classes I want at the times that are convenient for me," and "I don't think they really value what I bring to the table here." 
She also stated that she had never been in a union before and really held no strong opinions on unions, "I've never really thought about it. It just does not come up in academia very often and that's where I've mostly worked."

Andrew has been teaching at the subject university for five years and teaches a broad range of courses in the IT field. He currently also works as a self-employed consultant on data security. He has applied for three full-time openings at the subject university and received one interview. He holds a terminal degree in IT. He described his overall relationship with the subject university as "usually OK, although I think they generally treat adjuncts as slave labor." He also stated that he had at one time "wanted to file a grievance over the way the administration treated me once, but there is really no mechanism here for adjuncts to do that." He described his relationship with the students as "the usual, my courses are tough and students usually blame faculty when they don't do well." He stated that he generally had no strong opinions on the role of labor unions in higher education, "It just never comes up, especially for adjunct faculty." He also stated that "My father was a professor and he absolutely hated the idea of unions."

Josh has been teaching at the subject university for one year and teaches one section of an IS course and also one section of a freshman studies course. He holds two Masters Degrees, one in IS and one in Communication. He currently also does adjunct teaching at another college and is actively seeking a full-time faculty position. He is also currently pursuing a terminal degree in IS. He described his relationship with the subject university as, "pretty much OK, I'm really focused on getting a full-time position at the other school I teach at, and so this place is pretty much just for experience." He also stated that he thought, "Adjuncts never really get a chance here anyway." He also stated that he thought he has a "very positive" relationship with the students and commented that, "my course evaluations are always very good." He stated that he had been in a union in a previous job and thought that, "the dues were a lot considering that I never really needed the union to do anything, but I guess they were OK." His general impressions regarding unions were "pretty positive" and he stated that "I think I was one of the first people that actually signed one of those union cards here."

Hazel has been teaching at the subject university for nine years and usually teaches the maximum number of courses permitted for adjuncts each term, usually in information management areas. She has an MS Degree in Computer Science and is not currently pursuing a terminal degree. She stated that, "My husband is a full-time employee at the university so I don't really need a full-time job here, but it sure would be nice." She has applied for several full-time faculty openings at the subject university only and was interviewed twice. She described her relationship with the university as "wonderful, it's a great place to work" and her relationship with the students as "the best part of my job." She stated that her impressions of unions were generally positive, "They have a union here for the full-timers and my husband is in it and I think it has been great for us." She also stated that she had never been in a union herself and at the beginning of the process was highly apprehensive because of her husband's status at the subject university.

Adam has been teaching at the subject university for six years and generally teaches introductory courses in IS. He holds a terminal degree in IT and also teaches part-time at two other universities, although generally he teaches no more than 3 classes a semester combined. He also has a full-time position in the IT field as a quality inspector and was not interested in a full-time faculty position. He stated, "I like the teaching, but it really does not pay like the private sector does." He said that his general impressions on labor unions were "not really very positive although I've never actually been in one," and that, "unions really seem to be on the way out, so I'm not sure if that's the kind of thing I want to be a part of." He also stated that he had a few incidents with the administration that, "maybe in some instances it would have been nice to have a support system in place for adjuncts since no one really cares about us here."

\section{Data Collection}

After initially screening potential subjects and reviewing confidentiality issues, each participant was given an informed consent document outlining expectations on issues such as content and confidentiality. After obtaining informed consent from the seven participants, an in-depth interview was held with each of them. Each interview followed a semi-structured format designed to capture the 'experience' of each participant during the process of moving from anon-union environment to the final vote for unionization. An interview protocol was developed and used during this phase of the study. The protocol was reviewed by three subject matter experts (two on qualitative research methods and one on labor relations management) to establish validity of the questions used in the protocol. 
Interviews ranged from 60 to 90 minutes and were conducted at an off campus location to protect the anonymity of the participants. Each interview was audio recorded and then transcribed. To ensure maximum reliability in the data, each interview was transcribed by two researchers and then the transcripts were compared to assure the accuracy of the data. As case studies often include the use of archival data or physical artifacts in addition to personal interviews, memos and letters sent by both the university and the union organizers were also reviewed.

\section{Data Analysis}

After the interviews were transcribed, they were initially reviewed. This within-case analysis provided initial familiarity with the data. The data were then coded for themes. Two separate coders were used and the results comparted to ensure consistency and reliability. One of the major challenges in this case study was the establishment of epoche, a process by which the researcher excludes any personal bias or judgment when reviewing the data $[31,33]$. This was especially challenging since one of the researchers was also an adjunct faculty member at the subject university and had also experienced the unionization process at the university. This necessitated the use of the second coder.

Cross-case analysis was then used to facilitate insights beyond preliminary impressions. Themes began to emerge as the data was coded and analyzed. Enumeration and categorization of the data were also performed at this stage. Finally, the transcriptions and general themes enumerated were given back to the participants to further validate that the researchers had correctly captured the meaning and essence of each participant's experiences during this process of potential unionization.

\section{RESULTS}

Three critical components emerged as important perceptual issues among the participants as they experienced the process of unionization. These included; issues of isolation and confusion, mixed messages, and fear of uncertainty. These factors were consistent with the literature on this subject. Further investigation revealed that within each of these major thematic areas, three sub-factors were present in each area. These sub-factors included: communication, interpersonal relationships, and commitment to the university. Each of these sub-factors influenced, to varying degrees, the major themes that emerged.

Issues of Isolation and Confusion - This issue was cited by each participant and is often discussed in the literature during any change process, so the inclusion of this theme was not surprising to the researchers $[17,20,38,39]$. What was somewhat surprising was the degree to which the participants felt that this theme occurred throughout the entire unionization process. For these participants issues of isolation and confusion were consistently discussed as one of the most impactful aspects of the process. Among the key words and phrases that were used to code for this domain included, "I felt all alone", "Was not sure who I could talk to", "Completely isolated", "Did not understand what was going on", and "Was completely confused about the whole thing."

Communication: Issues regarding communication leading to isolation and confusion were discussed by all seven participants in this study. What appeared to bind this theme was a feeling of not knowing who they could talk to about the process that was happening all around them. John commented, "What was strangest for me was how quiet the adjunct faculty office was all semester. No one talked about anything." Josh echoed this sentiment, "The office used to be a pretty lively place, but once this all started, people were very quiet and kept to themselves." Allison's comments exemplify the feelings of confusion that were discussed by all seven participants in the area of communication, "because this was such an important topic it would have been nice to have some objective conversation about it, but no one seemed to know very much and no one wanted to talk about the issue." Andrew added, "I've never been in a union and frankly did not know too much about them, so the lack of communication by all of us really added a high level of confusion."

Interpersonal Relationships: Feelings of isolation and confusion were described by six of the participants as impacting their interpersonal relationship with adjunct colleagues, full-time faculty members, and administrators. All six who commented on this during their interviews discussed how significant this area had been for them. Hazel stated, "Because you never really knew who was for or against this union thing, people just kept to themselves and really did not engage each other like they did before this whole thing started." Adam added, "You almost tried to 'size up' the other people in the room on the union issue before you really talked to them and so generally I just did 
not talk to anyone." One particularly telling comment came from John, "I was in the office and three people were ranting about how terrible the whole union thing was, since I supported the idea, it really impacted how I acted around those guys for the rest of the semester. I was guarded and did not really hang out with them to the degree I did before."

Commitment to the University: To varying degrees, issues of isolation and confusion affected the degree to which the participants felt committed to the university. This issue was raised by five of the participants and manifested itself in an overall opinion that the university did not appear, in the eyes of these participants, to be vested in them personally. Andrew commented, "I always felt like our school, and especially our department were one big happy family. This process changed that for me. I really began to see higher education as a business and started to understand that's how the school viewed me, as an asset and nothing more." Allison echoed this sentiment, "Although I was leaning towards being supportive of the union idea, I never got the feeling that the school cared about my welfare as a person, just how much it was going to cost them."

Mixed Messages - The receipt of mixed messages was the most discussed theme by six of the seven participants. The emergent theme was also consistent with the literature on unionization movements $[4,13,26]$. Each participant commented on how radically different the messages on the opposing sides (university and union organizers) of the issues were. The perceived animosity between the two sides (which was mentioned by five of the participants) caused strong emotional reactions from the participants. The theme of receiving mixed messages during any strong emotional change is consistent with the literature. Some of the key words and phrases used to code this theme included, "mixed signals", "mixed messages", "conflicting viewpoints", "I had no idea what they really wanted", and "they said one thing one time then the total opposite the next."

Communication: Communication was discussed as an issue by all seven participants and each participant commented on how impactful the communication messages were for them. Josh stated, "Seriously, this was the worst part of the whole thing. Both sides had completely opposite perspectives, which made it really hard to know which side, if either was right." Allison added, "I don't really understand how the administration could see absolutely no value in a union while at the same time the union just said terrible things about the administration. It just made it so hard to figure out what to believe." Four of the participants commented on how the mixed messages in communication soured them a bit on the process. Richard added, "I got to the point where I just stopped reading any emails about the union from either side. They were just so biased that it was not worth my time and it really just made me irritated."

Interpersonal Relationships: Six of the participants commented on how perceived mixed messages impacted their relationships with peers and administrators. Five participants mentioned that changes in interpersonal relationships as one of the most disappointing aspects of this process. Adam stated, "The worst part of it for me was how this impacted how I felt about the administration. I thought they at least supported the idea of better conditions for adjuncts, but the moment this process started, it seemed like they thought we were the enemy." This was further amplified by Josh, "I was always on good terms with my department head, but after this process started she would say things like, 'I support you guys' but then we'd get a memo from her telling us that nothing would change or improve if a union came in. I never really trusted her the same after that." Additionally, relationships with colleagues were also strained. Richard stated, "sometimes faculty, especially the full-timers would tell you that a union would never help us get more money which really seemed odd since they have had their own union for like five years and their salaries go up all the time."

Commitment to the University: All seven participants commented on how the mixed messages sent by both sides impacted their relationship with and commitment to the university. The very polarizing messages received by both sides caused each, to varying degrees, to become less committed long term to the university. An exemplar of this attitude was expressed by Andrew, "I always thought I would teach here forever, I used to think we were all here for the same reasons. This process really showed that when push comes to shove, the administration just sees us as a cost they need to control. If could find another job that paid as well I'd jump in a minute." Hazel added, "One of the best things about working at a university is the collegiality of everyone, but I think that's gone now. They, and by that I mean the administration, created an 'us versus them' mentality." None of the participants blamed the union organizers for this adversarial relationship. John stated, "It's the union's job to get people fired up, but I thought the university would at least be open to a rational dialogue, but no, they just care about money." 
Fear of Uncertainty - Consistent with the literature, issues of uncertainty during a unionization process were discussed by all participants $[1,13,29]$. This perception caused anxiety for the participants, one of the most consistent issues they described was that both sides were actively trying to use this uncertainty to manipulate them to vote a certain way. Josh stated, "I don't think either side really cared about us, both just wanted to win and we were like pawns in their little power game and however it turned out, you sure as heck did not want to be on the losing side." Each participant also commented on how stressful the uncertainty was during this process, Allison added, "Both sides gave you a 'doom scenario' so you were terrified either way. I never knew what was going to happen if we got a union or not." Key words and phrases used to code for this theme included, "uncertainty", "afraid", "future" and "who knows what comes next."

Communication: The uncertainty of the communication presented by both sides during the unionization process was discussed by six participants. Most of the communication was in the form of emails and letters from both union organizers and university administration. Although the union did host several open meetings, none of the participants attended them. Each participant expressed that both sides contributed to uncertainty. Richard stated, "You could never get a straight answer from either side. They would basically both say anything if it would get you to vote their way. The process was so stressful and I never really knew what would exactly happen if the union came into being or not." Hazel added, "I thought both sides did their fair share of fear mongering. While some administrators tried to play both sides of the fence saying how they were 'with us' in spirit and then talking about how they weren't sure they could offer us a class if the union came in, real nice." The issue of communication was summed up by Adam, "They wanted to keep us guessing and scared, and fearful of what would happen if we "voted the wrong way'."

Interpersonal Relationships: Interpersonal relationships were addressed by only three of the participants and focused on how the unionization process would affect long-term relationships they had with peers and administrators. Allison was one of the most outspoken participants on this issue and stated, "I like the people I work with. I always enjoy interacting and even talk to some of them socially. But now, you just don't know where people stand and who knows if seniority and other issues are going to drive a lot of people away. It's almost like starting over with everyone." That sentiment was echoed by John regarding his relationship with administrators, "Now that it's over, I guess we all have to rebuild some trust in each other. I'm hoping we all go back to supporting each other, but who knows."

Commitment to the University: Issues of fear of uncertainty in relation to commitment to the university were expressed by four of the participants. These comments typically fell into two distinct categories; a desire to renew a commitment to a long-term relationship with the university after the unionization process was complete or a rejection of any desire to buy into the university's position on faculty relations. Allison summarized the first position, "I think we would all now like to move forward. If the university is sincere in willing to work in this new dimension then I think we can all get along nicely. I'm sure that's what happened when the full-time faculty got their union. Now at least we all know what the standing of the issue is." John exemplified the other perspective, "Something like this can really sour you on where you work, that's what happened to me. Simply put, the effort the administration put into demonizing the idea of what a union would mean to the school was pure nonsense. It really showed me just how little value they place on us. It would take a long time to rebuild trust here and I don't think I'll be here long enough for that to happen."

While it may seem that the overall impact of this process on these participants was negative, several did voice some positive comments that should also be included in this discussion. Five of the participants commented that the experience, while somewhat challenging, did raise their expectations that future conditions would improve, especially in regard to pay. One exemplar of that feeling was given by Richard, "The good thing about this whole process is that, as tough as it has been for both sides, I think, in the end, we'll get our issues, especially pay, addressed." 


\section{CONCLUSIONS}

The results of the study indicated that for these participants the unionization process was more stressful than they had originally thought it would be and they perceived significant issues in the major themed areas of this study: isolation and confusion, mixed messages, and fear of uncertainty. At the conclusion of the unionization process, the adjunct faculty members voted overwhelmingly in favor of becoming part of a labor union. It appears that issues during the unionization process were impactful to these participants in a number of ways that present interesting challenges and opportunities to both union organizers and university administrators.

It appears that in the area of 'isolation and confusion' making a concerted effort on both parts to ensure that adjunct faculty perceive they are not treated as pawns and that both sides have unique and different perspectives might help alleviate some anxiety and stress in this area. It was interesting that for these participants most of the negative 'mixed messages' were blamed on the university and not the union. This is perhaps one of the key finding in this study. While both sides engaged in rhetoric aimed at demonizing the motives and future possibilities of the other side, the previously collegial relationship between adjunct faculty and the administration appeared to suffer most in this area. It is likely that for many of the participants there was always a tacit expectation that, in the end, the university really supported the adjunct faculty and that perception was shattered for some of them. Allison stated, "I've worked here long enough to know almost everyone and always thought we were all in this together as one big university. They really let me down with the negative and, in many ways, threatening tone of their messages. All I want is some security at a job I love and enough money to live, how can they not support that?" Adam also stated, "I felt kind of betrayed by my department head. I knew what the union was all about from the get go, but the school administration really surprised me with how ridiculously one-sided their opinions were." Another key finding was the degree to which uncertainty played into the perceptions of the participants. While fear of uncertainty is common in times of significant change, managing that change and presenting adjunct faculty with accurate and timely information and a consistent message might reduce this perception in future unionization movements of adjunct faculty.

While both union organizers and university administration had strategic aims and goals not discussed in this study, both seemed to lack an understanding of the issues faced by the very people most directly impacted by this effort at unionization. The depth of emotional responses on the part the participants in this study indicate that while unionization of adjunct faculty will remain an important issue in higher education, considerable effort should be expended to ensure that adjunct faculty members have a greater understanding of the process and how it can impact them. This might alleviate some of the challenges faced by adjunct faculty members during a potential unionization process.

\section{FUTURE RESEARCH}

The area of adjunct faculty unionization is a relatively new academic phenomenon and will in all likelihood be a significant issue for most universities. Therefore, understanding how adjunct faculty members perceive their relationships with universities, what issues they feel are most compelling and how they perceive the benefits and drawbacks of unionization are all critical factors for both universities and unions. Areas of future research might include broader sample sizes across faculty disciplines and exploring the perceptions of traditional labor organizations as they now embrace greater 'white collar' members. The long-term impact of labor unions in higher education will also be a rich area of future research. Other areas of research based upon this study might include a more long-term study on the aftermath of the unionization process and the relationship between full-time faculty (whether unionized or not) and the newly unionized adjunct faculty members. Additionally, a quantitative study on factors that influence adjunct faculty to either support or reject a call for unionization would be an important area of study.

\section{LIMITATIONS OF THE STUDY}

While the results of this qualitative study do indicate that participants perceived issues during the unionization process including issues related to isolation and confusion, mixed messages and fear of uncertainty, the results should be viewed with caution. The sample size was small and only drawn from one department within the university. The culture of that department may have played a role in how the participants perceived this process and 
that culture may be different from the overall university culture. Additionally, the nature of qualitative analysis itself often leaves room for different interpretations other than those reached by the researcher. However, within these limitations, the study does contribute to the body of knowledge on adjunct faculty unionization.

\section{REFERENCES}

1. Badigannavar, V., \& Kelly, J. (2005). Why are some union organizing campaigns more successful than others? British Journal of Industrial Relations, 43(3), 515-535. doi: 10.1111/j.1467-8543.2005.00367.x

2. Blader, S. L. (2007). What leads organizational members to collectivize? Injustice and identification as precursors of union certification. Organization Science, 18(1), 108-126.

3. Block, R. N. (1980). Union organizing and the allocation of union resources. Industrial and Labor Relations Review, 34, 101-113.

4. Braekkan, K. F. (2013). 'Union yes': The moderating effects of union instrumentality on psychological contract violations. Journal of Workplace Rights, 17(2), 219-237. doi: 10.2190/WR.17.2.f

5. Brett, J. M. (1980). Why employees want unions. Organizational Dynamics, 8, 47-59.

6. Chaison, G. N., \& Dhavale, D. G. (1990). A note on the severity of the decline in union organizing activity. Industrial and Labor Relations Review, 43, 366-373.

7. Dedman, D., \& Pearch, W. J. (2004). Perspectives on adjunct and other non-tenure faculty. Community College Enterprise, 10(1), 23-33.

8. Denzin N. K., \& Lincoln Y. S. (2005). The SAGE handbook of qualitative research. Thousand Oaks: Sage Publications.

9. De Turberville, S. R. (2004). Does the 'organizing model' represent a credible union renewal strategy? Work, Employment and Society, 8(4), 775-794. doi: 10.1177/0950017004047963

10. Deshpande, S. P., \& Fiorito, J. (1989). Specific and general beliefs in union voting models. Academy of Management Journal, 32(4), 883-897. doi: 10.2307/256573

11. Dickens W. T., \& Leonard J. S. (1985). Accounting for the decline in union membership, 1950-80. Industrial and Labor Relations Review, 38, 323-334.

12. Fiorito, J., Gall, G., \& Martinez, A. D. (2010). Activism and willingness to help in union organizing: Who are the activists? Journal of Labor Research, 31(3), 263-284. doi 10.1007/s12122-010-9092-3

13. Fiorito, J., \& Hendricks, W. (1987). The characteristics of national unions. Advances in Industrial and Labor Relations, 4, 1-42.

14. Fiorito, J., \& Jarley, P. (2010). Understanding organizing activity among US national unions. Journal of Industrial Relations, 41, 74-92.

15. Fiorito, J., \& Jarley, P. (2012). Union organizing and membership growth: Why don't they organize? Journal of Labor Research, 33(4), 461-486.

16. Fiorito, J., Jarley, P., \& Delaney J. T. (1995). National union effectiveness in organizing: Measures and influences. Industrial and Labor Relations Review, 48, 613-635.

17. Friedman, L., \& Harvey, R. J. (1986). Factors of union commitment: The case for a lower dimensionality. Journal of Applied Psychology, 71, 371-376.

18. Godard J. (2008). Union formation. In: Blyton, P., Bacon, N., Fiorito, J., \& Heery, E. (eds) Handbook of Industrial Relations. Sage: London.

19. Gordon, M. E., Philpot, J. W., Burt, R. E., Thompson, C. A., \& Spiller, W. E. (1980). Commitment to the union: Development of a measure and an examination of its correlates. Journal of Applied Psychology, 65, 479-499.

20. Hammer, T. H., Bayazit, M., \& Wazeter, L. M. 2009. Union leadership and member attitudes: A multi-level analysis. Journal of Applied Psychology, 94, 392-410.

21. Hurd, R. W. (2004). The failure of organizing, the new unity partnership, and the future of the labor movement. Work USA, 8, 5-25.

22. Jones, G. A. (2013). The horizontal and vertical fragmentation of academic work and the challenge for academic governance and leadership. Asia Pacific Education Review, 14(1), 75-83. doi: 10.1007/s12564-0139251-3

23. Kaufman, B. E., \& Stephan, P. E. (1995). The role of management attorneys in union organizing campaigns. Journal of Labor Research, 16(4), 439-454.

24. Kirk, F. R., \& Spector, C. A. (2009). A comparison of the achievements of students taught by full-time versus adjunct faculty in business courses. Academy of Educational Leadership Journal, 13(2), 73-81. 
25. Liftig, R. A. (2014). The American adjunct: Almost always a bridesmaid, almost never a bride. Journal of College Science Teaching, 43(3), 10-11.

26. Logan, J. (2006). The union avoidance industry in the United States. British Journal of Industrial Relations, 44(4), 651-675.

27. Martin, A. W. (2008). The institutional logic of union organizing and the effectiveness of social movement repertoires. American Journal of Sociology, 113, 1067-1103.

28. Martinez, A., \& Fiorito, J. (2009). General feelings toward unions and employers as predictors of union voting intent. Journal of Labor Research, 30(2), 120-134.

29. McClendon, J. A., Wheeler, H. N., \& Weikle, R. D. (1998). The individual decision to unionize. Labor Studies Journal, 23(3), 34-54.

30. McGee, M. (2002). Hooked on higher education and other tales from adjunct faculty organizing. Social Text, 20(1), 61-80.

31. Merriam, S. B. (1998). Qualitative research and case study applications in education: Revised and expanded from case study research in education. San Francisco, CA: Jossey-Bass.

32. Park, H., McHugh, P. P., \& Bodah, M. M. (2006). Revisiting general and specific union beliefs: The unionvoting intentions of professionals. Industrial Relations, 45(2), 270-289.

33. Podsakoff, P. M., MacKenzie, S. B., Lee, J., \& Podsakoff, N. (2003). Common method biases in behavioral research: A critical review of the literature and recommended remedies. Journal of Applied Psychology, 88, 879-903.

34. Rose J. B., \& Chaison, G. N. (2001). Unionism in Canada and the United States in the 21st century: The prospects for revival. Relations Industrielles/Industrial Relations, 56, 34-65.

35. Rogers, S. E., Eaton, A. E., \& Voos, P. B. (2013). Effects of unionization on graduate student employees: Faculty-student relations academic freedom and pay. ILR Review, 66(2), 487-510.

36. Schwab D. P. (2005). Research methods for organizational studies. Lawrence Erlbaum, Mahwah.

37. Schmidt, P. (2014, April 18). Power in numbers. Chronicle of Higher Education, 60(31). Retrieved from chronicle.com

38. Shulruf, B., Yee, B., Lineham, B., Fawthorpe, L., Johri, R., \& Blumenfeld, S. (2010). Perceptions, conceptions and misconceptions of organized employment. Journal of Industrial Relations, 52(2), 236-241.

39. Tetrick, L. E., Shore, L. M., McClurg, L. N., \& Vandenberg, R. J. (2007). A model of union participation: The impact of perceived union support, union instrumentality, and union loyalty. Journal of Applied Psychology, 92(3), 820-828.

40. U.S. Department of Labor, Bureau of Labor Statistics. (2011, January 21). Union Members in 2010. In USDL News Release USDL-11-0063. Retrieved June 19, 2015 from http://www.bls.gov/news.release/union2.nr0.htm

41. Voss, K., \& Sherman, R. (2000). Breaking the iron law of oligarchy: Union revitalization in the American labor movement. American Journal of Sociology, 106, 303-349. 